results suggest that effectiveness of AA depends on the method or animal species.

\title{
18. 田川市立病院歯科口腔外科において加療した知的障害者症例の検討
}

○天野 裕治·立石 晃

田川市立病院·歯口外

田川市立病院歯科口腔外科で平成 11 年 1 月から平成 15 年 12 月までの 5 年間に加療した知的障害者初診症例につ いて検討を行った，症例は 26 例であった，性別は，男性 11 例，女性 15 例であった。年齢別では, 10 歳代から 60 歳 代に広く分布し, 40 歳代が 9 例と多かった。疾患別では, 歯周疾患 6 例, 顎骨周囲炎 5 例, 歯根囊胞 3 例, 歯根膜炎 3 例などであった。 処置別では, 消炎処置 7 例, 歯周病治療 6 例, 抜歯 3 例, 囊胞摘出術 3 例などで, 口㓐外科処置 が 17 例であった. 入院治療は, 7 症例, 8 回で, 全身麻醉症例は, 4 例であった. 他医院からの紹介は, 13 例であっ た。当科における知的障害者症例は, 比較的高齢者の症例が多く, 口腔外科疾患症例が多かった。

Clinical study of mentally disabled patient cases treated in Department of oral maxillofasial surgery, Tagawa municipal hospital

Yuji Amano and Akira Tateishi (Department of Oral and Maxillofacial Surgery, Tagawa Municipal Hospital)

The first-medical-examination cases of mentally disabled patients in oral and maxillofacial surgery of Tagawa municipal hospital for the past five years were examined. The number of cases was 26 . Sex was 11 men and 15 women. The age ranged from the tens to the sixties and the forties were the highest with 9 cases. By disease there were six periodontal diseases, five permaxillary and perimandibular inflammation, three radicular cyst and three periodontitis cases. Medical treatment was given to seven anti-inflammatory, six periodontal, three exodontias and three cyst extraction treatments. Oral surgery-treatments were given to 17 cases. Hospitalization medical treatment was for seven cases and for 8 times, and the number of general anesthesia cases was four. The introduction from other hospitals was 13 cases. The mentally disabled patient cases in our department had many cases of oral surgery disease.

19. 終末期口腔癌患者の QOL Ver. 4 を用いた QOL 評価の試み

○立石 晃

田川市立病院·歯口外

終末期口腔癌患者の QOL 低下は明かではあるが, 障害の具体的内容の報告は少ない. 今回, UWQOL Ver. 4 を用 いて終末期口腔癌患者の QOL 評価を行ったので報告した. 田川市立病院歯科口腔外科にて終末期医療を行った口腔 癌患者 7 名を対象とした。性別は男性 4 名, 女性 3 名, 年齢は $62 \sim 87$ 歳で, 内訳は進展腫瘍で局所非制御 2 名, 頚 部非制御 4 名, 局所·頚部再発 1 名, 全例扁平上皮癌であった。調查は死亡 $2 \sim 5$ か月前に承諾を得た後に行った. 咀嚼, 味覚が最む障害が大きく, 続いて娛楽, 活動の順に障害を認めた。会話, 肩の障害は比較的少なかった。気持 ち, 不安は様々であり, 患者の背景因子である家族構成が大きく影響していた. 今回の QOL 調查によって患者自身の 問題点を医療スタッフが理解し，共有することが可能となった．終末期緩和医療を行う上で大变価値があった．

\section{QOL assessment of terminal stage of oral cancer patients by UWQOL Ver.4}

Akira Tateishi (Department of Oral and Maxillofacial Surgery, Tagawa Municipal Hospital)

The Head and Neck questonnaire (UWQOL) Ver. 4 was designed to be specific for head and neck patients. The scale consists of 12 categories, each describing important daily living dysfuction or limitations patients complain of as part of head and neck cancer. 12 categories are domains of pain, disfigurement, actibity, recreation, swallowing, chewing, speech, shoulder, taste, saliva, mood and anxiety. This paper showed the results of QOL assessment of terminal stage of oral cancer patients by UWQOL Ver. 4. UWQOL Ver. 4 were performed for 7 cases of terminal stage oral cancer at 2-5 months prior 